\title{
Calculation of efficiency of the project of modernization machining shop of the instrument-making enterprise
}

\author{
I. Fomina ${ }^{1, *}$, and $V$. Dreshchinsky ${ }^{1}$ \\ ${ }^{1}$ Faculty of economics and management, Saint-Petersburg State Electrotechnical University (LETI), Saint-Petersburg, Russia
}

\begin{abstract}
One of the directions of investment activity of the enterprise is investment into fixed assets which include processing equipment. Investment into processing equipment demands presence at the subject of information directorate about expenses and results of operation of the available equipment, knowledge of a current state of development of technology, ability to allocate various versions of projects of modernization, to estimate costs of acquisition, development and operation of the new equipment, abilities to compare projects in the specified parameters, to estimate their expediency and economic efficiency In work modern problems of achievement by the Russian industry of the level of efficiency and competitiveness meeting the requirements of the world market of the knowledge-intensive and hi-tech production, realization of innovative development of the enterprises with ensuring the corresponding growth rates for indicators of economic efficiency are considered. In this article the example of calculation of efficiency of the project of modernization of machining shop of the instrument-making enterprise (St. Petersburg) for participation in the FTP is given. The used numerical values have exclusively demonstration character.
\end{abstract}

\section{Introduction}

Achievement by the Russian industry of the level of efficiency and competitiveness meeting the requirements of the world market of the knowledge-intensive and hitech production can't be realized out of innovative development of the enterprises with ensuring the corresponding growth rates for indicators of economic efficiency.

One of key actions for increase of technical and economic indicators of fixed assets or their separate parts on the basis of introduction of the advanced equipment and technology, mechanization and automation of production, modernization and replacement of the outdated equipment with more productive new, is modernization of the enterprise [1].

\section{Concept of the project}

Thanks to the Russian Federal target program "Development of Defense Industry Complex of the Russian Federation for the Period till 2020" [2] many enterprises have had an opportunity to realize projects of modernization and modernization that has allowed them:

To come to qualitatively new level of technological capabilities conforming to the modern international standards of instrument making.

To restore ability to independently update the production capacities at the expense of a sinking fund, lost owing to crisis of national economy and instrumentmaking branch in 1991-2010.
It is considerable to reduce requirement of the enterprise for unique highly professional personnel which deficiency gains the menacing character [3] recently.

In this article an example of calculation of efficiency of the project of modernization of machining shop of the instrument-making enterprise for participation in the FTP will be reviewed. The used numerical values have exclusively demonstration character [20].

The term of implementation of the project it is expedient to take the term of effective use of the new equipment. According to the experts it is necessary to take term in 15 years.

Key parameters of the project are:

- The amount of financing - 425.6 million rubles.

- The term of performance of an investment stage -3 years.

- The term of implementation of the project (calculation of indicators of efficiency) - 15 years.

- Profit of the project -402.7 million rubles.

- Indicators of efficiency of the project.

- In the analysis of efficiency of the project it is necessary to calculate the following indicators:

- Profit of the project (NCF).

Profitability of investments.

- Payback period of the project (PP).

- Internal standard of profitability (IRR).

It should be noted that the discounting method in projects of this sort (so-called "internal" projects) usually isn't applied as in such cases the subject of investment not the financial investor who is looking for the

Corresponding author: i-fomina@inbox.ru 
maximum return on the capital and carrying out the choice of the investment project in various branches of economy, and the management of the enterprise having alternatives only at the choice of a way of implementation of the project, but not in the choice of the project [4].

General description of the project.

Replacement of the equipment of machining shop of the instrument-making enterprise assumes acquisition within 3 years of 16 processing centers and 2 control and measuring cars:

On this equipment it will be possible to carry out the production program which is carried out today by 155 units of the old equipment, the number of the main and auxiliary workers will be reduced by 59 people, the case spaces occupied today by machining shop (risk analysis is given by tab. 1) will completely be released $[5,6]$.

Table 1. Risk analysis of the investment project

\begin{tabular}{|c|c|c|c|}
\hline Type of risk & $\begin{array}{c}\text { Assessment of probability } \\
\text { of emergence of risk }\end{array}$ & $\begin{array}{c}\text { Assessment of extent of } \\
\text { influence of risk }\end{array}$ & Actions for decrease in risk \\
\hline \multicolumn{4}{|c|}{ The risks connected with start and implementation of the project: } \\
\hline $\begin{array}{l}\text { - divergence of expected } \\
\text { and actual volumes of } \\
\text { material resources }\end{array}$ & Low & Low & Don't need \\
\hline $\begin{array}{l}\text { - excess of the planned } \\
\text { expenses and prime cost } \\
\text { growth }\end{array}$ & Middle & Low & $\begin{array}{l}\text { Aren't required (increase in } \\
\text { prime cost in the project can } \\
\text { go only under the article } \\
\text { "depreciation", but her size is } \\
\text { more than four times blocked } \\
\text { by economy under other } \\
\text { articles). }\end{array}$ \\
\hline $\begin{array}{l}\text { - non-performance of the } \\
\text { plan for power, volume of } \\
\text { release, productivity }\end{array}$ & Middle & Middle & $\begin{array}{l}\text { Production diversification, } \\
\text { creation of an instrument- } \\
\text { making cluster on the basis of } \\
\text { the enterprise }\end{array}$ \\
\hline $\begin{array}{c}\text { - a delay of completion of } \\
\text { works on start of the } \\
\text { project }\end{array}$ & Middle & Middle & $\begin{array}{l}\text { Fixing of responsibility } \\
\text { through contracts }\end{array}$ \\
\hline $\begin{array}{l}\text { - limited availability of the } \\
\text { earth, energy, building } \\
\text { materials, raw materials, } \\
\text { transport }\end{array}$ & Low & Low & Don't need \\
\hline $\begin{array}{l}\text { - limited availability of } \\
\text { working resources, } \\
\text { administrative shots, } \\
\text { contractors }\end{array}$ & Low & Low & $\begin{array}{l}\text { Aren't required (one of the } \\
\text { project purposes - } \\
\text { minimization of this risk) }\end{array}$ \\
\hline $\begin{array}{l}\text { - possible changes of cost } \\
\text { of raw materials, materials, } \\
\text { equipment, finished goods }\end{array}$ & Middle & Low & $\begin{array}{l}\text { Aren't required (one of the } \\
\text { project purposes - } \\
\text { minimization of this risk) }\end{array}$ \\
\hline \multicolumn{4}{|c|}{ Macroeconomic risks: } \\
\hline $\begin{array}{l}\text { - adverse development of a } \\
\text { macroeconomic situation in } \\
\text { the country }\end{array}$ & Middle & Middle & $\begin{array}{l}\text { Doesn't give in to } \\
\text { management }\end{array}$ \\
\hline $\begin{array}{l}\text { - adverse change of an } \\
\text { exchange rate of ruble }\end{array}$ & Low & Low & Doesn't extent direct impact \\
\hline - decrease in demand & Low & Low & $\begin{array}{l}\text { Production diversification, } \\
\text { creation of an instrument- } \\
\text { making cluster on the basis of } \\
\text { the enterprise }\end{array}$ \\
\hline $\begin{array}{c}\text { - toughening of procedure } \\
\text { of pricing concerning } \\
\text { productions/services of } \\
\text { society } \\
\end{array}$ & Middle & Middle & $\begin{array}{l}\text { Aren't required (one of the } \\
\text { project purposes - } \\
\text { minimization of this risk) }\end{array}$ \\
\hline \multicolumn{4}{|c|}{ Other risks: } \\
\hline $\begin{array}{l}\text { - non receipt of } \\
\text { certification, the license in } \\
\text { government bodies }\end{array}$ & Low & Low & Don't need \\
\hline $\begin{array}{c}\text { - bankruptcy of suppliers / } \\
\text { contractors }\end{array}$ & Low & Low & Don't need \\
\hline
\end{tabular}




\section{Calculation of efficiency of the project}

Step 1: Investment (tabl. 2)

Table 2. Capital equipment.

\begin{tabular}{|c|c|c|c|}
\hline № & Price, rubles & Amount & Value, rubles \\
\hline 1 & 6780 & 2 & 13559 \\
\hline 2 & 8051 & 2 & 16102 \\
\hline 3 & 8898 & 2 & 17797 \\
\hline 4 & 15254 & 2 & 30508 \\
\hline 5 & 12712 & 2 & 25424 \\
\hline 6 & 25424 & 2 & 50847 \\
\hline 7 & 33898 & 4 & 135593 \\
\hline 8 & 5085 & 2 & 10169 \\
\hline & & 18 & 300000 \\
\hline
\end{tabular}

\section{Step 2: Retrofitting of the capital equipment}

In investment part of the project, except costs of acquisition of the capital production and measuring equipment stated above it is necessary to provide the costs of retrofitting of the acquired equipment connected with it, acquisition auxiliary the equipment and construction works in the case where it is supposed to place the modernized production sites.

Retrofitting of the equipment assumes single investments in a size 33 million 748 thousand rubles [11].

Table 3. Retrofitting of the equipment.

\begin{tabular}{|c|c|c|}
\hline № & Option & Value, rubles \\
\hline 1 & Retrofitting & 33748 \\
\hline & Total & 33748 \\
\hline
\end{tabular}

\section{Step 3: Service equipment}

The service equipment assumes expenses of 17 million 119 thousand rubles:

Table 4. Service the equipment.

\begin{tabular}{|c|c|c|c|c|}
\hline № & Option & $\begin{array}{c}\text { Price, } \\
\text { rubles }\end{array}$ & Amount & $\begin{array}{c}\text { Value, } \\
\text { rubles }\end{array}$ \\
\hline 1 & $\begin{array}{c}\text { Thermoins } \\
\text { tallation }\end{array}$ & 339 & 2 & 847 \\
\hline 2 & The case is tool & 127 & 16 & 2034 \\
\hline 3 & Compressor & 847 & 2 & 1695 \\
\hline 4 & Conditioner & 847 & 15 & 12712 \\
\hline & TOTAL & & & 17119 \\
\hline
\end{tabular}

\section{Step 4: Installation of the equipment}

At determination of cost of construction works it is possible to use given on already carried out re-equipment of part of the case (installation of 5 units of the modern equipment similar to purchased) [7]. Production of construction works assumes investments of 9 million 831 thousand rubles:

Table 5. Investments into constructions work.

\begin{tabular}{|c|c|c|c|c|}
\hline № & Option & $\begin{array}{c}\text { Price, } \\
\text { rubles }\end{array}$ & Amount & $\begin{array}{c}\text { Value, } \\
\text { rubles }\end{array}$ \\
\hline 1 & Bases & 508 & 10 & 5085 \\
\hline 2 & $\begin{array}{c}\text { Other } \\
\text { construction } \\
\text { works and } \\
\text { materials }\end{array}$ & 1186 & 4 & 4746 \\
\hline & TOTAL & & & 9831 \\
\hline
\end{tabular}

Thus, the total need for investments for implementation of the project makes 360 million 697 thousand rubles, and need for their financing (including the VAT) - 425 million 622 thousand rubles.

\section{Step 5: Single income}

Except investments the present project assumes also the single income: sale of the released (written-off) equipment at the beginning of the project and sale of the acquired equipment at the end of the term of his operation [12].

The weight of the written-off machines makes 202 tons that at today's market price of scrap metal of 10 thousand rubles for ton (with the VAT) will allow to realize machines for the sum 1 million 708 thousand rubles.

Besides, at the end of operation term the acquired equipment can be realized for $20 \%$ of its initial cost that will make 60 million rubles [10].

Table 6. Income from realization.

\begin{tabular}{|c|c|c|c|c|}
\hline № & Option & $\begin{array}{c}\text { Price, } \\
\text { rubles }\end{array}$ & Amount & $\begin{array}{c}\text { Value, } \\
\text { rubles }\end{array}$ \\
\hline 1 & $\begin{array}{c}\text { Sale of the } \\
\text { equipment after } \\
\text { operation term }\end{array}$ & $\mathrm{x}$ & $\mathrm{x}$ & 60000 \\
\hline 2 & $\begin{array}{c}\text { Sale of the released } \\
\text { equipment }\end{array}$ & 8.47 & 201.525 & 1708 \\
\hline & TOTAL & & & 61708 \\
\hline
\end{tabular}

Thus, investments of the project taking into account the single income will make 298 million 991 thousand rubles.

The current income and expenses on the project.

The current income of the project consists, mostly, of the economy under articles of the current expenses of the enterprise connected with implementation of the project.

Table 7. Distribution of investments in time.

\begin{tabular}{|c|c|c|c|c|c|}
\hline \multirow{2}{*}{ Items of expenditure / income } & \multicolumn{5}{|c|}{ Year of implementation of the project } \\
\cline { 2 - 6 } & $\mathbf{1}$ & $\mathbf{2}$ & $\mathbf{3}$ & $\ldots$ & $\mathbf{1 5}$ \\
\hline Expenses & & & & & \\
\hline Equipment & 100000 & 100000 & 100000 & 0 & 0 \\
\hline Retrofitting & 11249 & 11249 & 11249 & 0 & 0 \\
\hline Service equipment & 5706 & 5706 & 5706 & & \\
\hline Installation & 9831 & & & & \\
\hline
\end{tabular}




\begin{tabular}{|c|c|c|c|c|c|}
\hline Income & & & & & \\
\hline Sale of the released equipment & -569 & -569 & -569 & & \\
\hline Sale of the equipment after operation term & & & & & -60000 \\
\hline Total investments & 126217 & 116386 & 116386 & 0 & -60000 \\
\hline
\end{tabular}

Such articles are:

- Economy on a salary of the main and auxiliary workers of shop.

- Economy on repair of the equipment which is written off as a result of implementation of the project.

- Economy on the tool spent for work on the written-off equipment.

-Economy on the special equipment which was required for implementation of the production program on the written-off equipment.

- Economy on decrease in marriage [9].

Besides, the project assumes also increase of the income of the enterprise for the following directions:

The additional income from leasing of the floor spaces which are released as a result of implementation of the project.

The additional income (profit) on obtaining orders in cooperation [13].

The main operating costs of the project arise under the following articles:

- Expenses on the tool for work on the new equipment.

- Expenses on special equipment for the new equipment.

Except above-mentioned articles the project of replacement of the equipment mentions also other articles of the income and expenses. But, as the extent of economy, the income and expenses received on these to articles is rather small, we exclude them from consideration [17].

Economy. Salary of the main and auxiliary workers.

The staff list of the modernized shop looks as follows:

Table 8. Staff list.

\begin{tabular}{|c|c|c|c|}
\hline Group/specialty & Quantity & $\begin{array}{c}\text { Salary, } \\
\text { rubles }\end{array}$ & $\begin{array}{c}\text { Annual } \\
\text { salary, } \\
\text { thousand } \\
\text { rubles }\end{array}$ \\
\hline $\begin{array}{c}\text { Management personnel } \\
\text { shop }\end{array}$ & 38 & 22.8 & 10407 \\
\hline $\begin{array}{c}\text { Main workers, all } \\
\text { including: }\end{array}$ & 44 & 31.6 & 16710 \\
\hline operator-serviceman & 16 & 30.0 & 5760 \\
\hline foreman & 2 & 50.0 & 1200 \\
\hline mechanic & 5 & 27.5 & 1650 \\
\hline grinder & 2 & 25.0 & 600 \\
\hline turner & 5 & 37.5 & 2250 \\
\hline $\begin{array}{c}\text { milling-machine } \\
\text { operator }\end{array}$ & 5 & 37.5 & 2250 \\
\hline $\begin{array}{c}\text { workers of a foundry } \\
\text { site }\end{array}$ & 7 & 25.0 & 2100 \\
\hline Cutting machine & 1 & 37.5 & 450 \\
\hline turning and sentry & 1 & 37.5 & 450 \\
\hline $\begin{array}{c}\text { Auxiliary workers, in } \\
\text { total }\end{array}$ & 2 & 25.0 & 600 \\
\hline including: & 2 & 25.0 & 600 \\
\hline Total & 84 & 27.5 & 27717 \\
\hline
\end{tabular}

Actual data on the number and a salary of employees of machining shop for 2015 :
Table 9. Total salary.

\begin{tabular}{|c|c|c|c|}
\hline Group/specialty & Quantity & $\begin{array}{c}\text { Salary, } \\
\text { rubles }\end{array}$ & $\begin{array}{c}\text { Annual } \\
\text { salary, } \\
\text { thousand } \\
\text { rubles }\end{array}$ \\
\hline $\begin{array}{c}\text { Management personnel } \\
\text { shop }\end{array}$ & 38 & 22.8 & 10407 \\
\hline Main workers & 81 & 28.4 & 27581 \\
\hline Auxiliary workers & 24 & 21.3 & 6122 \\
\hline TOTAL & 143 & 25.7 & 44110 \\
\hline
\end{tabular}

Thus, the economy on a wages fund makes 16 million 393 thousand rubles a year, and taking into account taxes on a salary -21 million 967 million a year.

The above-stated data paid off on the basis of 2015 . At implementation of the project growth of a salary by 2,81 times in 15 years is considered ( 1 and $2-$ on $10 \%$ of growth, from 3 to 5 year - on $20 \%$ of growth, from 6 to 15 year - on $3 \%$ of growth). Such assumptions are caused by the following reasons:

Continuous growth of deficiency of skilled workers of shots at simultaneous stagnation of system of their preparation is observed that causes higher growth rates of a salary in this segment of labor market.

Indicators of the enterprise for a salary of workers are at the moment lower the middle year.

Strategy of the enterprise has provided the essential growth of a salary in 2016-2018.

Fully the economy on a salary arises for the $3 \mathrm{rd}$ year of implementation of the project.

For the term of implementation of the project the economy of a salary and tax charges on a salary will make 684 million 201 thousand rubles.

Economy. Repair of the equipment.

For definition of economy under the article "repair and service of the equipment" data on services of nonproductive departments to machining shop and costs of services of the third-party organizations carried on machining shop for the last 6 years have been analysed. The average size of expenses under this article for the written-off equipment has made 4 million 752 thousand rubles a year.

It should be noted the following facts:

- data of the last years are higher than the specified average size;

- eventually expenses on repair and service of the old equipment will grow;

- growth of the production program is predicted.

Owing to these factors in the project growth of costs of repair of the old equipment twice in 15 years is put that in opinions of experts is minimum possible growth.

Fully the economy on repair and service of the equipment arises for the 3 rd year of implementation of the project.

For the term of implementation of the project the economy under the article "repair and service of the equipment" will make 130 million 039 thousand rubles. 
Economy. Tool and special equipment.

Average costs of purchase and production of the tool and of production and repair of special equipment for the last 6 years have made about 500 thousand rubles and 1 million rubles a year respectively. The specified sizes belong to the written-off equipment.

Fully the economy on the tool and special equipment arises for the 3rd year of implementation of the project. The economy calculates taking into account the planned growth of the production program. [16]

For the term of implementation of the project the economy under the article "expenses on purchase and production of the tool" will make 12 million 440 thousand rubles, and under the article "expenses on production and repair of special equipment" - 24 million 879 thousand rub.

Income. Leasing of the released areas.

As a result of implementation of the project the case spaces occupied today by machining shop which make 3 825 sq.m. will completely be released. At present the area of this case can lease a minimum on 200 rub for 1 sq.m. a month. Respectively, the annual revenue will make at least 7 million 780 thousand rubles.

The income from delivery of the areas for rent arises for the 4th year of implementation of the project as time for write-off and export of the old equipment will be required.

For the term of implementation of the project the income from rent will make 93 million 356 thousand rubles.

Income. The income from obtaining orders in cooperation.

Park of the new equipment from the most modern machines which will be available the enterprises in 3 years after the beginning of the project, will allow to solve many production and technological and many other instrument-making enterprises of the country and city. The solution of a question of development production has only organizational restrictions for today especially as development of such cooperation is provided as the operating strategy of development of the enterprise. [18]

If to assume that the enterprise will be able to allocate about $3 \%$ of capacities of the machines which are purchased on the project (4 200 hours of useful work year) and $25 \%$ of profitability at production cost of release, then the income of the project under the article "cooperation" (net profit from orders in cooperation) will make 3 million 146 thousand rubles a year. According to the experts this size is minimum possible $[8,9]$.

This type of income is provided, since 4 years of implementation of the project.

For the term of implementation of the project the income under the article "cooperation" will make 37 million 968 thousand rubles.

Expenses. The tool and special equipment for the new equipment.

Expenses on the tool for the new equipment are calculated on the basis of tool expenditure statistics on the operated modern equipment similar purchased, and make 285,7 thousand rubles on 1 machine a year.
Expenses on special equipment paid off proceeding from set service life the specialist of equipment in 5 years and costs of a set, a component of 33 million 748 thousand rubles.

Expenses on the tool and special equipment during the project are taken taking into account growth of the production program twice for the 5th year of implementation of the project.

For the term of implementation of the project expenses on the tool for the new equipment will make 125 million 108 thousand rubles, and on special equipment for the new equipment - 158 million 642 thousand rubles.

\section{Conclusion}

- Thus, the project has the following indicators of efficiency:

- Profit (NCF) of 402 million 776 thousand rubles.

- Profitability of investments of $135 \%$.

- Payback period of 9 years from the moment of the beginning 6 years from the moment of an exit at full capacity.

Internal standard of profitability of $11,8 \%$.

The provided analysis shows that the project is favorable to the enterprise.

Depreciation of the new equipment.

In the analysis of efficiency of the project it should be noted that except articles of economy and the income given above, in the project there is one more essential plus - the depreciation which is saved up during operation of the new equipment which will allow to update further the equipment on a regular basis without attraction of essential investments from profit and/or from outside.

Depreciation on the economic essence isn't an expense - it is part of prime cost, transfer of already made investment expenses in prime cost small parts for the accounting of these expenses in production price. On an economic essence depreciation is an income, the fund formed by the enterprise for purchase of fixed assets [19].

In the considered project increase in depreciation charges won't affect prime cost and profit of the enterprise as increase in prime cost within $3-4 \%$ is compensated by decrease in the current expenses. Therefore, any outflows of money, in connection with increase in depreciation charges in calculation of efficiency it isn't necessary to provide [15].

Everything for the project 312 million 535 thousand rubles will be added to revenues.

If to consider depreciation of the equipment in efficiency calculation, then we will receive the following results:

- Profit (NCF) of 715 million 311 thousand rubles.

- Profitability of investments of $239 \%$.

Payback period of 6 years from the moment of the beginning 3 years from the moment of an exit at full capacity

Internal standard of profitability of $23,4782 \%$. 
Payback and internal standard of profitability of the project

The payback period of the project is defined by summation of investments of the project and a flow of the income of the project. Summation is carried out by every year by the accruing result, investments of the project are considered as negative sizes, return of investments - as positive [14].

\section{References}

1. A Guide to the Project Management Body of Knowledge (PMBOK Guide), (Project Management Institute Publ., 2013).=

2. Review of Approaches in Modeling Adaptive Business Process, Proc. of the 10th Conference of Open Innovations Association FRUCT and the 2nd Finnish-Russian Mobile Linux Summit, 24 (2011)

3. I.A. Brusakova, Proc. Modern Problems of Management, 3 (2015)

4. I.A. Brusakova, M.A. Kossukhina, Proc. modern problems of applied informatics, 6 (2012)

5. I.A. Brusakova, M.A. Kossukhina, Proc. SCM (2015)

6. D. Katalevsky, The Basics of Simulations and System Analysis in Management (Delo Publ., Moscow, 2015)

7. H.J. Zimmermann, Fuzzy Set Theory and Its Applications (Kluwer Academic Publishers, Boston, 1996)

8. Avalaible: http://www.metodolog.ru.

9. I.A. Brusakova, Proc. 2015 IV Forum Strategic Partnership of Universities and Enterprises of HiTech Branches, 77 (2015). DOI: 10.1109/IVForum.2015.7388260.
10. I.A. Brusakova, V.I. Fomin, M.A. Kossukhina, S.N. Panin, Research of development trends of information management in modern conditions (Publishing house of Saint-Petersburg University. Univ of Management and Economics, St. Petersburg, 2014)

11. I.A. Brusakova, Proc. 2015 IV Forum Strategic Partnership of Universities and Enterprises of HiTech Branches, 77 (2015). DOI: 10.1109/IVForum.2015.7388260.

12. K. Beck, Extreme Programming Explained: Embrace Change (Addison-Wesley Professional Publ., 1999)

13. T.A. Khudyakova, A.V. Shmidt, Mediterranean Journal of Social Sciences, 6(4), 274 (2015)

14. M.A. Kossukhina, Proc. of the 12th Conference of Open Innovations Association FRUCT and eTourism seminar, 41 (2012)

15. M.A. Kossukhina, Proc. Modern Problems of Management, 55 (2015)

16. M.A. Kossukhina, H. Aminov, Proc. of the 12th Conference of Open Innovations Association FRUCT and e-Tourism seminar, 37 (2012)

17. S.N. Ostapenko, N.Yu. Fedoseyev, A methodical grant for manufacturing small and medium-sized enterprises for questions of modernization and modernization (Moscow, 2010)

18. O.A. Shvetsova, News of LETI, 3, 75 (2015)

19. O.A. Shvetsova, News FINEC magazine, 4(56), 65 (2008)

20. O.A Shvetsova., I.A. Brusakova, A.V. Zvontsov, I.G Fomina, Proc. SGEM, 47 (2015)

21. T.A. Khudyakova, A.V. Shmidt, Mediterranean Journal of Social Sciences, 6(4), 274 (2015) 